\title{
Possible effects of feeding fish the dried-treated sewage on bioaccumulation of metals, morphological lesions and mortality rate
}

\author{
Abdelhamid M. Abdelhamid; Ahmed I. Mehrim and Moustafa A. Alkatan, \\ Department of Animal Production, Faculty of Agriculture, Al-Mansoura University, Egypt.
}

\section{ABSTRACT}

A feeding field experiment was conducted for 102 days, using a polyculture system (Nile tilapia, silver carp, common carp, and African catfish at a rate 1:1:1:1) in two Hapas, one for control fish fed a commercial diet and the second one fish were fed on a dried sewage sludge (DSS). The control diet, DSS, fish body and muscles were analyzed for metals contents. Throughout the experimental period, any symptoms and death cases were recorded. From the obtained results, it was clear that DSS contained very high percentage of ash and very low percentages of ether extract (EE) and total carbohydrate percentages comparing with the diet of the control group. It was found that DSS contains higher levels of $\mathrm{P}, \mathrm{Cu}, \mathrm{Pb}$, and $\mathrm{Cd}$ than the commercial control diet. The P and Cd levels were higher in DSS fed fish than the control ones, regardless of the fish species. However, catfish body contained the highest level of $\mathrm{P}$ and $\mathrm{Cu}$ but silver carp body contained the highest $\mathrm{Pb}$ and $\mathrm{Cd}$ levels. The interaction effect (dietary treatment $\times$ fish species) was significant, except for $\mathrm{Cu}$. The control fish muscles presented higher contents of $\mathrm{Cu}, \mathrm{Pb}$, and $\mathrm{Cd}$, but the opposite was true for $\mathrm{P}$, where the DSS fed fish contained significantly higher level of $\mathrm{P}$ in their muscles than the control fish, silver carp contained significantly higher $\mathrm{Cu}$ and $\mathrm{Cd}$ and tilapia contained the highest level of $\mathrm{Pb}$ in the muscles comparing with the other fish species, regardless of the dietary treatment. The interaction effect was significant. Fish fed on DSS were darker with friable livers comparing with the control fish. Concerning mortality rate, when the fish were fed on the DSS, silver and common carps were more tolerant than the Nile tilapia and catfish. Therefore, it is recommended to give more concern on food and water quality (environmental friendly) used in aquaculture to offer safe products for human consumption.

Keywords: Sewage sludge, fish, heavy metals, bioaccumulation, survival rate.

\section{INTRODUCTION}

Most of the Egyptian (marine, brackish, and fresh) water bodies is contaminated with agricultural, industrial, and urban drainage, which is responsible for their water and fish pollution with different heavy metals (Abdelhamid et al., 2006a and 2013a\&b) at levels exceeding the Egyptians' tolerance limits (ES, 1993 and Abdelhakeem et al., 2002). Heavy metals polluted water is causative for ca. thirty-two danger disease (Abdelhamid, 2006). So, many intoxications could be occurred in humans consume fish reared under polluted water conditions (Abdelhamid and ElAyoty, 1991; Shata, 1996 and Abdelhamid et al., 1999) or fed on contaminated diets (Abdelhamid, 1983 and Abdelhamid et al., 1996).This year (2014) will be a milestone year where the per capita consumption of farmed fish will be greater than wild fish consumption (Koeleman, 2014).

Different wastes are frequently used in fish feeding (Abdelhamid, 2014a) from plant, animal and/or variable sources (Abdelhamid et al., 2012a\&b; Ibrahim et al., 2012; Khalafalla et al., 2012; Abdelhakim et al., 2013; Abdelhamid and Soliman, 2013 and Abou-Ziedet al., 2013). Plant and animal wastes are used too as organic 
fertilizers for fish ponds (Agouz and Gomha, 2011 and Abdelhamid, 2014b). In this respect, sewage sludge may be used in aquaculture. However, the use of untreated night soil as a fertilizer as a source of nutrients in fish farming presents a considerable health hazard in the form of pathogens and parasites. Moreover, fish ponds receiving nutrients derived from treated night soil were less contaminated than ones to which untreated night soil was applied, and the fish reared in them were of superior quality (Ling et al., 1993).So, a field study was conducted to evaluate the effects of feeding dried sewage sludge (DSS) on the heavy metals content, morphological lesions and mortality rate of four fish species (Nile tilapia, common carp, silver carp, African catfish), for 102 days.

\section{MATERIALS AND METHODS}

\section{The experimental management:}

This study was conducted during the summer season in a private fish farm at Tolompat 7, Alriad, Kafr El-Sheikh governorate, Egypt. Nile tilapia, silver carp and African catfish were purchased from a private fish farm, Kafr El-Sheikh governorate, Egypt. While, the common carp were purchased from Integrated Fish Farm at AlManzala (General Authority for Fish Resources Development, Ministry of Agriculture) Al-Dakahlia governorate, Egypt. Fish were stocked into a netHapa for two weeks as an adaptation period, during this period fish fed on a basal diet.

Fish were distributed into two experimental treatments (in 2 net Hapas); in the first treatment (the control group), fish were fed on the basal diet, whereas in the second treatment, fish were fed on DSS. Each Hapa $(8 \times 3 \times 1 \mathrm{~m})$ was constructed and implanted in an earthen pond (irrigated from agricultural drainage). Four fish species were distributed with an average initial body weight of Nile tilapia $(O$. niloticus) $178 \pm 3.5 \mathrm{~g}$, common carp (Cyprinuscarpio) $232 \pm 2.7 \mathrm{~g}$, silver carp (Hypophthal-michthysmolitrix) $344 \pm 4.3 \mathrm{~g}$ and African catfish (Clarias gariepinus) $408 \pm 3.2 \mathrm{~g})$. Stocking density was 100 fish / Hapa at a rate of 1: 1: 1: 1 for each fish species.

The basal diet was purchased from the local market. This commercial diet contained yellow corn, soybean meal ( $44 \%$ crude protein), wheat bran, fish meal ( $65 \%$ crude protein), corn gluten ( $60 \%$ crude protein), lime stone, common salt, dicalcium phosphate, and molasses and had not less than $25 \%$ crude protein, $3 \%$ crude lipids, $3935 \mathrm{Kcal}$ gross energy $/ \mathrm{Kg}$ diet, and not more than $5.30 \%$ crude fiber, according to the manufacture's formula.

The DSS was obtained from the duple stage treatment project (Sanitary Drainage Station Al-Riadcity, Kafr El-Sheikh governorate, Egypt). The basal diet and DSS were offered once daily $(10: 00 \mathrm{am})$ at $5 \%$ of the fish biomass at each Hapa. The feed quantity was adjusted each 21 days according to the actual fish body weight changes. The chemical analysis for the basal diet (control) and DSS was illustrated in Table 1. DSS seems to be CP-richer than the control diet; yet, DSS contains very high percentage of ash and very low percentages of EE and total carbohydrate percentages comparing tothe control diet.

Through all the intervals period of the experiment, any symptoms and death cases of the experimental fish were recorded by a digital camera, CASIO, Exilim optical 3x, 6.0 Mega pixels, 2.5" LCD, Anti-shake DSP, CASIO Computer Co., LTD., Tokyo, Japan. 
Table 1: Chemical composition of the basal diet and dried sewage sludge.

\begin{tabular}{|l|c|c|}
\hline \multirow{2}{*}{ Composition } & \multicolumn{2}{|c|}{$\%$ dry matter basis } \\
\cline { 2 - 3 } & Control (C) diet & Dried sewage sludge (DSS) \\
\hline Dry matter, DM & 92.75 & 92.12 \\
\hline Crude protein, CP & 25.75 & 30.21 \\
\hline Ether extract, EE & 3.56 & 0.89 \\
\hline Ash & 6.42 & 41.54 \\
\hline Total carbohydrate & 64.27 & 27.36 \\
\hline
\end{tabular}

\section{Elements determination:}

Some elements were determined in basal diet (control), DSS, fish whole body and muscles in the Agricultural Balance Box, Ministry of Agriculture, Cairo, Egypt. Perkin Elmer atomic absorption spectrophotometer (AAS) model 2380 equipped with MHS-10 hydride generation system was used for the quantitative determination of the studied elements ( $\mathrm{P}, \mathrm{Cu}, \mathrm{Pb}$ and $\mathrm{Cd}$ ) according to Abdallah and Mostafa (1980), Welz and Meleher (1985), Medina et al. (1986) and Abdallah et al. (1993).The tested elements were analyzed using an air/acetylene (flow rate of 5.5/1.1 Vm) flame atomic absorption spectrophotometer. The burner height was $8 \mathrm{~cm}$, fuel flow 30, oxidant flow 60 , and slide width $0.7 \mathrm{~nm}$. Blank samples from the used chemicals, as well as specked samples (internal standards) were undertaken to correct the obtained data.

Statistical analysis:

Numerical data collected were statistically analyzed using SAS (2001) software package (version 9.2) to detect the overall effects of treatments $\left(T_{1}-T_{2}\right)$. All percentages were arcsine-transformed prior to statistical analyses.The differences between mean of treatments were compared using Duncan's post hoc significant test (Duncan, 1955), and differences were considered statistically significant at $\mathrm{P} \leq 0.05$.

\section{RESULTS AND DISCUSSION}

\section{Bioaccumulation of somemineralelements:}

Table 2 presents mean values of some mineral elements of the tested diets. It is clear that DSS contains $162 \mathrm{P}, 5829 \mathrm{Cu}, 103 \mathrm{~Pb}$, and $109 \% \mathrm{Cd}$ more than the commercial control diet. This may be due to human activities in which man consumes huge amounts of different detergents containing $\mathrm{P}$, as well as the fertilizers containing $\mathrm{Cu}$, since their wastes are carried over the waste water onto DSS. This was reflected in the analysis of the fish body (Table 3), only for P and Cd which was higher in DSS fed fish than the control ones, regardless of the fish species. However, catfish contained the highest $(\mathrm{P} \leq 0.05)$ level of $\mathrm{P}$ and $\mathrm{Cu}$, but silver carp contained the highest $\mathrm{Pb}$ and $\mathrm{Cd}$ levels. The interaction effect (dietary treatment $\times$ fish species) was significant, except for $\mathrm{Cu}$, where the highest $(\mathrm{P} \leq 0.0001) \mathrm{P} \%$ was found in DSS fed catfish but $\mathrm{Pb}$ and $\mathrm{Cd}$ were found at highest levels in control silver carp and DSS fed common carp, respectively (Table 4).

Table 2: Concentration of some mineral elements in the tested diets.

\begin{tabular}{|l|c|c|}
\hline Mineral elements & Control diet & Dried sewage sludge (DSS) \\
\hline $\mathrm{P}(\%)$ & 0.93 & 1.515 \\
\hline $\mathrm{Cu}(\mathrm{ppm})$ & 1.75 & 102 \\
\hline $\mathrm{Pb}(\mathrm{ppm})$ & 1188 & 1218.5 \\
\hline $\mathrm{Cd}(\mathrm{ppm})$ & 113 & 123.25 \\
\hline
\end{tabular}


Table 3: Determination of some mineral elements in the whole body of the experimented fish according to the dietary treatments or to the fish species.

\begin{tabular}{|l|c|c|c|c|}
\hline Category & $\mathrm{P}(\%)$ & $\mathrm{Cu}(\mathrm{ppm})$ & $\mathrm{Pb}(\mathrm{ppm})$ & $\mathrm{Cd}(\mathrm{ppm})$ \\
\hline Treatments & $3.34^{\mathrm{b}}$ & $0.52^{\mathrm{a}}$ & $1100.7^{\mathrm{a}}$ & $108.1^{\mathrm{b}}$ \\
\hline Control diet & $3.79^{\mathrm{a}}$ & $0.00^{\mathrm{b}}$ & $1080.1^{\mathrm{b}}$ & $111.0^{\mathrm{a}}$ \\
\hline Dried sewage sludge & 0.010 & 0.010 & 1.208 & 0.293 \\
\hline \pm SE & 0.0001 & 0.002 & 0.0001 & 0.0001 \\
\hline P- value & \multicolumn{5}{|l|}{} \\
\hline Species & $3.31^{\mathrm{c}}$ & $0.450^{\mathrm{ab}}$ & $1082.5^{\mathrm{b}}$ & $110.2^{\mathrm{a}}$ \\
\hline Tilapia (T) & $3.31^{\mathrm{c}}$ & $0.000^{\mathrm{b}}$ & $1132.2^{\mathrm{a}}$ & $111.2^{\mathrm{a}}$ \\
\hline Silver carp (Sc) & $3.45^{\mathrm{b}}$ & $0.000^{\mathrm{b}}$ & $1087.2^{\mathrm{b}}$ & $110.5^{\mathrm{a}}$ \\
\hline Common carp (Cc) & $4.18^{\mathrm{a}}$ & $0.600^{\mathrm{a}}$ & $1059.7^{\mathrm{c}}$ & $106.2^{\mathrm{b}}$ \\
\hline Catfish (Cf) & 0.014 & 0.144 & 1.709 & 0.414 \\
\hline \pm SE & 0.0001 & 0.016 & 0.0001 & 0.0001 \\
\hline P- value &
\end{tabular}

Mean values in the same column for each category superscripted with different letters differ significantly.

Table 4: Interaction effect on some mineral elements in the whole body of the experimented fish.

\begin{tabular}{|c|c|c|c|c|c|c|c|c|c|c|}
\hline \multirow{2}{*}{ Treat. } & \multicolumn{4}{|c|}{ Control diet } & \multicolumn{4}{|c|}{ Dried sewage sludge } & \multirow{2}{*}{$\pm \mathrm{SE}$} & \multirow{2}{*}{ P-value } \\
\hline & $\mathrm{T}$ & $\mathrm{Sc}$ & $\mathrm{Cc}$ & $\mathrm{Cf}$ & $\mathrm{T}$ & $\mathrm{Sc}$ & $\mathrm{Cc}$ & $\mathrm{Cf}$ & & \\
\hline$P$ & $3.13^{\mathrm{c}}$ & $3.73^{\mathrm{a}}$ & $2.90^{\mathrm{d}}$ & $3.60^{\mathrm{b}}$ & $3.50^{\mathrm{c}}$ & $2.90^{\mathrm{d}}$ & $4.00^{\mathrm{b}}$ & $4.76^{\mathrm{a}}$ & 0.02 & 0.0001 \\
\hline $\mathrm{Cu}$ & $0.90^{\mathrm{ab}}$ & $0.00^{\mathrm{b}}$ & $0.00^{\mathrm{b}}$ & $1.20^{\mathrm{a}}$ & 0.00 & 0.00 & 0.00 & 0.00 & 0.204 & 0.16 \\
\hline $\mathrm{Pb}$ & $1072.5^{\mathrm{d}}$ & $1156.5^{\mathrm{a}}$ & $1092.0^{\mathrm{b}}$ & $1082.0^{\mathrm{c}}$ & $1092.5^{b}$ & $1108.0^{\mathrm{a}}$ & $1082.5^{\mathrm{c}}$ & $1037.5^{\mathrm{d}}$ & 2.417 & 0.0001 \\
\hline $\mathrm{Cd}$ & $106.5^{b}$ & $111.5^{\mathrm{a}}$ & $106.5^{b}$ & $108.0^{b}$ & $114.0^{\mathrm{a}}$ & $111.0^{\mathrm{b}}$ & $114.5^{\mathrm{a}}$ & $104.5^{\mathrm{c}}$ & 0.586 & 0.0001 \\
\hline
\end{tabular}

Mean values in the same row superscripted with different letters differ significantly.

Table 5 presents also the data of the same minerals but in the fish muscles, where the control diet-fed fish presented higher $(\mathrm{P} \leq 0.0001)$ contents of $\mathrm{Cu}, \mathrm{Pb}$, and $\mathrm{Cd}$, but the opposite was true for $\mathrm{P}$ where DSS fed fish contained significantly higher level of $\mathrm{P}$ in their muscles than the control fish (Table 5) without significant $(\mathrm{P} \geq$ $0.05)$ effect of fish species on $\mathrm{P} \%$; yet, silver carp contained significantly $(\mathrm{P} \leq 0.0001)$ higher $\mathrm{Cu}$ and $\mathrm{Cd}$ and tilapia contain the highest level of $\mathrm{Pb}$ in the muscles comparing with the other fish species, regardless of the dietary treatment. The interaction effect was significant $(\mathrm{P} \leq 0.0001)$ with the highest values of $\mathrm{P}$ in muscles of DSS fed catfish, $\mathrm{Cu}$ in control common carp, and $\mathrm{Pb}$ and $\mathrm{Cd}$ in muscles of the control tilapia (Table 6).

Table 5: Some mineral elements in the muscles of the experimented fish according to the dietary treatments or to the fish species.

\begin{tabular}{|l|c|c|c|c|}
\hline Category & P (\%) & Cu (ppm) & Pb (ppm) & Cd (ppm) \\
\hline Treatments & $1.075^{\mathrm{b}}$ & $325.1^{\mathrm{a}}$ & $1112.5^{\mathrm{a}}$ & $111.6^{\mathrm{a}}$ \\
\hline Control diet & $1.116^{\mathrm{a}}$ & $164.8^{\mathrm{b}}$ & $1051.7^{\mathrm{b}}$ & $107.1^{\mathrm{b}}$ \\
\hline Dried sewage sludge & 0.005 & 0.408 & 0.763 & 0.375 \\
\hline \pm SE & 0.0001 & 0.0001 & 0.0001 & 0.0001 \\
\hline P- value & 1.083 & $115.5^{\mathrm{d}}$ & $1111.0^{\mathrm{a}}$ & $113.0^{\mathrm{a}}$ \\
\hline Species & 1.100 & $340.3^{\mathrm{a}}$ & $1103.5^{\mathrm{b}}$ & $113.5^{\mathrm{a}}$ \\
\hline Tilapia (T) & 1.100 & $314.8^{\mathrm{b}}$ & $1019.0^{\mathrm{d}}$ & $101.5^{\mathrm{c}}$ \\
\hline Silver carp (Sc) & 1.100 & $209.2^{\mathrm{c}}$ & $1095.0^{\mathrm{c}}$ & $109.5^{\mathrm{b}}$ \\
\hline Common carp (Cc) & 0.008 & 0.577 & 1.080 & 0.530 \\
\hline Catfish (Cf) & 0.412 & 0.0001 & 0.0001 & 0.0001 \\
\hline \pm SE &
\end{tabular}

Mean values in the same column for each category superscripted with different letters differ significantly. 
Table 6: Interaction effect on some mineral elements in the muscles of the experimented fish.

\begin{tabular}{|l|c|c|c|c|c|c|c|c|c|c|}
\hline \multirow{2}{*}{ Treat. } & \multicolumn{4}{|c|}{ Control diet } & \multicolumn{4}{c|}{ Dried sewage sludge } & \multirow{2}{*}{ P- } & \multirow{2}{*}{$\begin{array}{c}\text { PE } \\
\text { value }\end{array}$} \\
\cline { 2 - 10 } & $\mathbf{T}$ & $\mathbf{S c}$ & $\mathbf{C c}$ & $\mathbf{C f}$ & $\mathbf{T}$ & $\mathbf{S c}$ & $\mathbf{C c}$ & $\mathbf{C f}$ & & \\
\hline $\mathbf{P}$ & $1.100^{\mathrm{a}}$ & $1.100^{\mathrm{a}}$ & $1.100^{\mathrm{a}}$ & $1.000^{\mathrm{b}}$ & $1.066^{\mathrm{b}}$ & $1.100^{\mathrm{b}}$ & $1.100^{\mathrm{b}}$ & $1.200^{\mathrm{a}}$ & 0.011 & 0.0001 \\
\hline $\mathbf{C u}$ & $6.266^{\mathrm{c}}$ & $564.7^{\mathrm{a}}$ & $566.0^{\mathrm{a}}$ & $163.5^{\mathrm{b}}$ & $224.7^{\mathrm{b}}$ & $116.0^{\mathrm{c}}$ & $63.76^{\mathrm{d}}$ & $255.0^{\mathrm{a}}$ & 0.816 & 0.0001 \\
\hline $\mathbf{P b}$ & $1140.5^{\mathrm{a}}$ & $1082.5^{\mathrm{c}}$ & $1088.5^{\mathrm{b}}$ & $1138.5^{\mathrm{a}}$ & $1081.5^{\mathrm{b}}$ & $1124.5^{\mathrm{a}}$ & $949.5^{\mathrm{d}}$ & $1051.5^{\mathrm{c}}$ & 1.527 & 0.0001 \\
\hline $\mathbf{C d}$ & $114.5^{\mathrm{a}}$ & $113.5^{\mathrm{a}}$ & $109.0^{\mathrm{b}}$ & $109.5^{\mathrm{b}}$ & $111.5^{\mathrm{ab}}$ & $113.5^{\mathrm{a}}$ & $94.0^{\mathrm{c}}$ & $109.5^{\mathrm{b}}$ & 0.75 & 0.0001 \\
\hline
\end{tabular}

Mean values in the same row superscripted with different letters differ significantly.

In this context, activated sludge, chicken manure and pig manure were tested for their toxic effects as supplementary feeds for the common carp, Cyprinus carpio. High heavy metal concentrations ( $\mathrm{Pb}, \mathrm{Cu}, \mathrm{Zn}$ and $\mathrm{Mn}$ ) were found accumulated in the flesh of the fish fed the wastes. It is suggested that waste materials should be pretreated and detoxified before using them as animal feeds (Wong et al., 1982). Additionally, trace metal content of different parts of tilapia, Oreochromis mossambicus, fed sludge cake as supplementary feeds was studied. The sludge supplementary diets had significantly higher $(\mathrm{P}<0.05)$ amounts of all the trace metals tested $(\mathrm{Cd}, \mathrm{Cu}, \mathrm{Cr}, \mathrm{Ni}, \mathrm{Pb}$ and $\mathrm{Zn}$ ) compared to the control diet (Wong and Chiu, 1993). However, Rashed and Awadallah (1994) showed that $\mathrm{Cd}$ and $\mathrm{Pb}$ concentrations were clearly high in the scale and vertebral column than in the other parts of the fish (flesh, gills, stomach, intestine and liver).

Abdelhamid (1988) cited that $83.3 \%$ of the tested samples of different industrial waste water were refused according to the law no. 48/1982. Moreover, Abdelhamid and El-Zareef (1996) registered the following values for P: $0.21,1.18$ and $1.34 \%$ in rearing water (El-Manzalah Lake), tilapia and catfish, respectively; and for $\mathrm{Cu}: 0.01$, 5.71 and 7.81 with bioaccumulation factors for both elements 8259-10858 and 452678 in tilapia and catfish, respectively, reflecting the species variation.

Abdelhamid and El-Ayoty (1991) found also that aquatic inorganic pollutants $(\mathrm{PbCl} 2$ and $\mathrm{AlCl} 3$, but not the organic $\mathrm{Pb})$ caused mortality among catfish besides pathological findings e.g. hemorrhages, and congestion of the gastrointestinal tract and kidneys, reflecting the variation due to source of pollutants. Additionally, Abdelhamid et al. (2006b) proved that all stressors negatively affect fish blood (hematology and biochemistry) and immunity, hence growth performance.

Bioaccumulation of pollutants can occur from solution or through food chain. Great toxicity of some pollutants than others can be attributed to their faster penetration rather than to their tissue affection. However, some species acquire gradual tolerance by frequent exposure to sublethal levels of these pollutants. In this respect, Abdelhamid and El-Zareef (1996) confirmed the presence of toxic levels of muscular $\mathrm{Cu}$ (in catfish in winter) and $\mathrm{Zn}$ (in catfish and tilapia in summer and winter) in Lake Manzala. Also, Abdelhamid et al. (1997) reported variations in the elements levels in fish due to locations, seasons, and fish species. They found that $\mathrm{Pb}$ and $\mathrm{Cd}$ levels in fish muscles were over the permissible international levels, as well as Abdelhakeem et al. (2002) cited the tolerance limits of $\mathrm{Pb}, \mathrm{Fe}$ and $\mathrm{Cd}$ in fish water as $0.10,0.35$ and $0.10 \mathrm{ppm}$, respectively and in fish body as 2, 30 and $0.5 \mathrm{ppm}$, respectively. Also, the bioaccumulation of copper, lead, zinc and chromium in the liver, intestine, ovary, muscles and brain in four fishes, Channa punctatus, Tilapia mossambica, Catlacatla and Labeorohita, in a sewage-fed ecosystem was detected (Deb and Santra, 1997).Yet, the Egyptians' standards are $0.1 \mathrm{ppm} \mathrm{Pb}$ and $\mathrm{Cd}$ in food fish (ES, 1993).Moreover, Abdelhamid et al. (1997) evaluated $\mathrm{Pb}$ and $\mathrm{Cd}$ in fish 
muscles from El-Manzalah Lake which were more frequently in Mugil cephalus than Liza ramada than Sparus aurata, reflecting variation among fish species in the metabolism of pollutants.

Generally speaking, metals target multiple organ systems and exert their toxic effects via an interaction of the free metal with the target: enzyme system, membranes, or cellular organelles. Metals exposure leads to specific immunotoxic consequences. It is important to remember that at high concentrations, metals usually exert immunosuppressive effects; however, at lower concentration, immunoenhancement is often observed. Metals decrease the resistance to the bacterial and viral pathogens (Klaasser, 2001).

However, Abdelhamid and Gawish (2002) found that most of the heavy metals were more concentrated in Mediterranean sea than in Lake Manzalah water, and $\mathrm{Cd}$ was $\leq \mathrm{Pb}$ in the edible parts of shrimp and crab. In addition, $100 \%$ of shrimp and crab samples were refused for their higher Cd-content and 35.7 and $42 \%$ because of higher $\mathrm{Pb}$ than the permissible levels. All the elements (except $\mathrm{Hg}$ ) were more concentrated in shrimp wastes than its flesh. They stated that it is a must to treat the pollution sources before their reach to the water bodies, and consumption of such aquatic organisms should be restricted to avoid public health risks. In this respect also, Abdelhamid et al. (2006a and 2013b) advice to take considerations from the responsible authorities for treating all kinds of waste waters before reaching water bodies to protect aquatic life and consumers. Yet, Abdelhamid et al. (2000) concluded that muscles of fish only are suitable for human consumption, since the pollution state of rearing water and fish in River Nile is bad which necessitate the application of the environmental laws to protect fish production and quality which is reflected on the human (consumer) health. However, fish bioaccumulate higher $\mathrm{Cu}$ and $\mathrm{Pb}$ than their muscles (Abdelhamid et al., 2013b). Anyhow, Abdelhamid et al. (2013a) ranked the elements level in water as $\mathrm{Cd} \geq \mathrm{Pb} \geq \mathrm{Cu}$ and in fish as $\mathrm{Pb} \geq \mathrm{Cu} \geq \mathrm{Cd}$.

Ibrahim (2003) cited that hazards of certain aquatic pollutants are not only due to their high toxicity but also to their longevity and persistence in the environment. Moreover, Abdelhamid et al. (2013a) reported that the presence of a heavy metal in a fish body may not be followed its presence in the surroundings sediments or water. It may depend on its solubility, target medium, site of its location, as well as on different water quality criteria (salinity, $\mathrm{pH}$, alkalinity, dissolved oxygen, microbial load....etc), sediment and fish species (differing in the metabolism). Where, Mugil cephalus L. showed higher levels of $\mathrm{Pb}$ concentrations than Sparus aurata L. (Yilmaz, 2005). This may be due to the store tissue of each metal in the fish, i.e. $\mathrm{Pb}$ is probably an external pollutant (Rashed and Awadallah, 1994), whereas Cd is internal pollutant. Therefore, $\mathrm{Cd}$ contents of fish affected positively their BAFs, but $\mathrm{Pb}$ was not.

The concentrations of lead, cadmium, chromium, copper, and zinc in the sewage-fed pond water, sediment, and the various organs of Labeorohita, Catlacatla, Cirrhinusmrigala, Oreochromis mossambicus, and Cyprinus carpio cultured in sewage-fed pondswere investigated by Adhikariet al. (2009). Also, they reported thatsignificant $(\mathrm{P} \leq 0.05)$ differences were observed among the five fish species for all these metals accumulation. Cadmium showed the least bioaccumulation, while zinc showed the highest bioaccumulation in all the fish species. Though the metal concentration in the different fish tissues was variable, the highest concentration was found in kidneys and the lowest in the muscles. Concentrations of these metals in the muscle tissue of all the fish species were well below the consumption safety tolerance in fish set by WHO/FAO, and thus, so far as these metals are concerned, this sewage fed cultured fishes are safe and suitable for human consumption. Some significant 
correlations were calculated among heavy metals (in water and fish) and chemical composition of the fish (Abdelhamid et al., 2013b).

Fish muscles bioacumulated higher $\mathrm{Pb}$ than $\mathrm{Cu}, \mathrm{Fe}$, and $\mathrm{Zn}$, respectively. The $\mathrm{Fe}$ accumulation was highest in the whole fish body followed by $\mathrm{Zn}, \mathrm{Cu}$ and $\mathrm{Pb}$, respectively. It was clear that each of $\mathrm{Zn}, \mathrm{Cu}$, and $\mathrm{Fe}$ were more bioaccumulated in the whole fish body than in the fish muscles. This may depend on the target organ for each element where it deposits. There were significantly positive correlations between $\mathrm{Pb} / \mathrm{Cu}$ and $\mathrm{Pb} / \mathrm{Cd}$ in fish muscles, whole fish $\mathrm{Zn} /$ muscular $\mathrm{Fe}, \mathrm{Cd} / \mathrm{Cu}, \mathrm{Cu} / \mathrm{Fe}$ as well as $\mathrm{Cd} / \mathrm{Pb}$ in whole fish, whole fish $\mathrm{Fe} /$ muscular $\mathrm{Fe}$, water $\mathrm{Zn} /$ muscular $\mathrm{Cd}$, water $\mathrm{Cu} /$ muscular $\mathrm{Cu}, \mathrm{Cu} / \mathrm{Zn}$ in water, water $\mathrm{Fe} /$ muscular $\mathrm{Fe}$, water $\mathrm{Fe} /$ whole fish $\mathrm{Cu}$, water $\mathrm{Fe} /$ whole fish $\mathrm{Fe}$, and $\mathrm{Fe} / \mathrm{Pb}$ in water. Also, there were significantly negative correlations between water $\mathrm{Cu}$ /whole fish $\mathrm{Pb}$ and water $\mathrm{Fe} /$ muscular $\mathrm{Cu}$ (Abdelhamid et al., 2013a). The lowest bioaccumulation factors were calculated in fish muscles; therefore, muscles only are suitable for human consumption. The effects of varying sampling locations and fish parts on the heavy metal level or presence were reported by Abdelhamid et al. (2000). Also, it is a fact that body adaptive balance mechanisms for lead impacts were evident in different organ tissues of fish.

Water, sediments and fish organs from Lake Manzala showed greater concentrations of most of the studied metals ( $\mathrm{Fe}, \mathrm{Zn}, \mathrm{Cu}, \mathrm{Mn}, \mathrm{Cd}$ and $\mathrm{Pb}$ ) than those from Lake Edku and Lake Borollus. $\mathrm{Fe}, \mathrm{Mn}, \mathrm{Cd}$ and $\mathrm{Pb}$ (in Lake Manzala) and $\mathrm{Mn}$ and $\mathrm{Pb}$ in Lake Borollusrecorded levels above the international permissible limits in water. Gills and liver of $O$. niloticus contained the highest concentration of most the detected heavy metals, while muscles appeared to be the last preferred site for the bioaccumulation of metals. The edible part of O. niloticus showed higher levels of $\mathrm{Cd}$ (in Lake Edku and Manzala) and $\mathrm{Pb}$ (in Lake Manzala). Nile tilapia caught from these two Lakes may pose health hazards for consumers (Saeed and Shaker, 2008). However, the concentrations of $\mathrm{Cu}, \mathrm{Fe}$, and $\mathrm{Zn}$ in water and edible part of fish were found below the notified toxic limits (Saeed and Mohammed, 2012).

Generally, from the human health point of view, Shata (1996) concluded that the surveillance of heavy metals in exposed persons is useful biologic monitoring tool to detect early asymptomatic conditions, as well as improvement and treatment of sewage disposal and directing it away from the lake to minimise its pollution. However, according to the ministerial decision No. 254/2003, the sewage (night soil) that may be used in agricultural purposes must not contain heavy metals (in $\mathrm{mg} / \mathrm{kg}$ ) than $39 \mathrm{~Pb}, 1500 \mathrm{Cu}$, and $300 \mathrm{~Pb}$.

\section{Morphological lesions:}

Fish showed the discoloration effect of DSS feeding on different fish species, particularly silver carp and catfish (Fig. 1 a - c).Fish fed DSS were darker with friable livers comparing to the control fish (fed the artificial diet). These harmful morphological lesions on fish may be optimistically related with bioaccumulations of the toxic metals in tested diets (Table 2), fish whole body (Tables 3 and 4) and fish muscles (Tables 5 and 6) of the experimental fish. However, bioassay using the marine bacteria, Vibrio fischeri and rotifer, Brachionu splicatilis, and chemical analyses were conducted to assess the toxicity of the various sewage sludges. Values by bioassay clearly revealed different toxicity levels depending on the sludge sources. High concentrations of heavy metals were measured in the samples from the industrial wastes and urban sewage sludge. However, there was no significant correlation between pollutant concentration levels and the toxicity values of the sludge (Park et al., 2005). 


\section{Mortality rate:}

Table 7 shows the mortality rate among the tested fish species throughout the 102 days experimental period that averaged between 0 and $12 \%$. The obtained data confirmed that Nile tilapia (T) was the best followed by catfish (Cf), silver carp (Sc) and lastly common carp $(\mathrm{Cc})$, when fed the commercial (control) diet. But, fish fed DSS revealed that Sc and Cc were more tolerant than T and Cf. The negative effect of feeding DSS on the mortality rate may be due to its very high content of ash and very low percentages of EE and total carbohydrate comparing to the commercial (control) diet (Table 1), as well as due to the long period of exposure time (102 days). That affected also negatively the growth performance and feed utilization (Abdelhamid et al., 2014, complementary study to the present study). Also, the present study suggests a strong link between metals bioaccumulation in rearing water, fish body and muscles from one side and the morphological lesions and the survival rateof the experimental fish from the other side. All carp exposed to raw sewage died within $6 \mathrm{~h}$. After 48 hours, 10, 40, and $90 \%$ of exposed carp survived in 50, 20, and $10 \%$ sewage, respectively. Forty-eight hours of exposure to 50 and $20 \%$ sewage caused severe pathological changes in the gills. In 50 and 20\% sewage, heart rate and respiratory frequency increased briefly, and then decreased gradually (Kakutaand Murachi, 1997).

Table 7: Mortality rate of the experimented fish after 102 days at feeding period.

\begin{tabular}{|l|c|c|}
\hline Treatment & Fish species & Mortality, \% \\
\hline Control diet & Nile tilapia & 0 \\
\cline { 2 - 3 } & Silver carp & 8 \\
\cline { 2 - 3 } & Common carp & 12 \\
\cline { 2 - 3 } & Catfish & 4 \\
\hline \multirow{5}{*}{ Dried sewage sludge } & Nile tilapia & 8 \\
\cline { 2 - 3 } & Silver carp & 0 \\
\cline { 2 - 3 } & Common carp & 0 \\
\cline { 2 - 3 } & Catfish & 12 \\
\hline
\end{tabular}

Trout (Salmotruttafario) were kept in two cages in a moderately polluted river at a site where a sewage plant discharges. River water only flowed through one cage (river water only (RWO) trout), while treated sewage water was added to the river water (final concentration 5\%) in a second cage (river and wastewater (RWW) trout).As a reference, fish were kept in tap water (tap water reference (TWR) trout).After 66 days the mortality rate in group RWW was $87 \%$, in group RWO $29 \%$ and in group TWR 0\% (Escher et al., 1999). AbdElaziz and Ehab (2003) reported that using poultry droppings and viscera as food for fish led to tremendous effects on some important water parameters. This treatment affected drastically the health condition (mortality) of cultured tilapia. Salem (2003) also found that $\mathrm{Cd}, \mathrm{Cu}$ and $\mathrm{Pb}$ reduced survival rate, but increased the residual concentration in fish tissues.

The obtained results in the present study revealed that the bioaccumulation of some toxic metals not only the tested diets and fish body, but also in the fish muscles (the edible part for human consumption). Where, it is reflected in both morphological lesions and mortality rate of the experimental fish. No doubt, these drastic effects related with the presence of some pollutants from agricultural and urban drainages whether in the rearing water or in the sewage sludge that can negatively affect fish health, production, and quality as well as could be inter the food chain and threat human health; so, it is recommended to give more concern on food and water quality 
(environmental friendly) used in aquaculture to offer safe products for human consumption.

\section{REFERENCES}

Abdallah, A. M. and Mostafa, M. A. (1980). Aflame molecular emission method for the determination of strontium in fresh waters. Annalidichimica by Societa Chimica Italibana, 70: $1-8$.

Abdallah, A. M., El-Dafrawy, M. M., Nazar, N. and El-Shamy, M. (1993). Elimination of the interfering of transition metals in the hydride generation atomic absorption spectrometric determination of tin. J. Atomic Absorption Spectrophotometer, 8: 759 .

AbdElaziz, M. A. and Ehab, I. M. (2003). Risk assessment of using of poultry droppings and poultry viscera as feeds for cultured tilapia and catfish (Clariaslazera), evaluation of their tremendous effects on water, fish, as well as their human health hazards. Proc. Conf. Fish Wealth and Food Safety in Arab and Islamic Countries.Azhar Univ., 22-24 Oct., 18p.

Abdelhakeem, N. F., Bakeer, M. N. and Soltan, M. A. (2002). Aquatic Environment for Fish Culture. Deposit No. 4774/2002.

Abdelhakeem, N. F.; Elgarhy, M. A. and Sayed, S. H. (2013).Studies of the use of fermented fish silage in diets for all male Nile tilapia (Oreochromisniloticus Lin.). Egyptian J. Nutrition and Feeds, 16 (2): 501 (Summary).

Abdelhamid, A. M. (1983). Mykotoxin-Nachweis in Lebens-und Futtermitteln des subtropischen Klimas. In: Kurzfassungen der Vorträgezur 37. Tag. Ges. Ernährungsphysiol. Haustiere, Göttingen, 5. Z. Tierphysiol., Tierernährug u Futtermittelkde., 50: 4-5.

Abdelhamid, A. M. (1988). How we avoid the environmental pollution sources? Development \& Environment, 18: 47-51.

Abdelhamid, A. M. (2000). Pollution of aquatic environment. Proc. Forum "Fish Wealth Development-Principles and Limitations", Mansoura Univ., May 9, pp: 225-233.

Abdelhamid, A. M. (2006). Heavy metals pollution of the Egyptian aquatic media. The $2^{\text {nd }}$ Inter. Sci. Con. For Environment "Recent Environmental Problems and Social Sharement", 28-30 March, South Valley University. p. 127 - 153.

Abdelhamid, A.M. (2014a). Fish Nutrition. An Arabic Textbook, Al-Mansoura Univ., $415 \mathrm{p}$.

Abdelhamid, A.M. (2014b). The Blue Revolution (Pesciculture).An Arabic Textbook, Al-Mansoura Univ., 674p.

Abdelhamid, A.M. and El-Ayoty, S.A. (1991). Effect of catfish (Clariaslazera) composition of ingestion rearing water contaminated with lead or aluminum compounds. Arch. Anim. Nutr., Berlin, 41: $757-763$.

Abdelhamid, A. M. and El-Zareef, A. A. M. (1996). Further studies of the pollution status on the southern region of El-Manzalah Lake. Proc. Food Borne Contamination and Egyptian's Health Conference, 26 - 27 Nov., pp. 141 - 150.

Abdelhamid, A. M. and Gawish, M.M. (2002). Studies on some trace metal contents of shrimp and crab from Mediterranean shore of Damietta governorate. Proc. $2^{\text {nd }}$ Conf. Foodborne Contamination and Egyptian's Health, 23-24 April, ElMansoura, Egypt, pp: 185-199. 
Abdelhamid, A.M. and Soliman, A.A.A. (2013).Comparative evaluation for dietary inclusion of some medical plants by common carp fish. Egyptian J. Nutrition and Feeds, 16 (2): 485-499.

Abdelhamid, A. M., Abdelghaffar, A. A. and El-Kerdawy, A. A. (2000). Towards causative interpretation of the repeatedly sudden and collective death of fish in Damietta region. J. Agric. Sci. Mansoura Univ., 25: 1947-1962.

Abdelhamid, A. M., El-Barbary, M. I. and Mabrouk, E. M. E. (2013a).Some heavy metals status in Ashtoum El-Gamil Protected Area. J. Arabian Aquacult. Soc., 8 (1): 69-86.

Abdelhamid, A. M., El-Kerdawy, A. A. El-Mezaein, A. A. M. and Meshref, H. A. (1997). Study on pollution in the western-north region of El-Manzalah Lake, Egypt. II. Heavy metals [Iron, zinc, lead and cadmium] in water, soil, and fish. J. Agric. Sci. Mansoura Univ., 22: 1877-1885.

Abdelhamid, A. M., El-Mansoury, A. M., Osman, A.I. and El-Azab, S.M. (1999). Mycotoxins as causative for human food poisoning under Egyptian conditions. J. Agric. Sci., Mansoura Univ., 24: 2751 - 2757.

Abdelhamid, A. M., Gawish, M. M. M. and Soryal, K. A. (2006a). Comparative study between desert cultivated and natural fisheries of mullet fish in Egypt, Iconcerning heavy metals. J. Agric. Sci. Mansoura Univ., 31: 5665 - 5680.

Abdelhamid, A. M., Gomaa, A. H. and El-Sayed, H. G. M. (2013b).Studies on some heavy metals in the River Nile water and fish at Helwan area, Egypt. Egypt. J. Aquat. Biol. \& Fish., 17 (2): 105 - 126.

Abdelhamid, A. M., Khalil, F. F. and Ragab, M. A. (1996).Survey of aflatoxin and ochratoxin occurrence in some local feeds and foods. Proceeding of conference on Food Borne Contamination and Egyptian's Health, Mansoura Univ., Nov. 26-27, pp: 43-50.

Abdelhamid, A. M., Maghraby, N. A, Mehrim, A. I. and Soliman, A. A. A. (2012a).Impact of non-conventional feedstuffs on growth performance and nutrients utilization of Nile tilapia fish. Egyptian J. Nutrition and Feeds, 15 (1 Special Issue): 349-357.

Abdelhamid, A.M., Maghraby, N. A., Mehrim, A. I. and Soliman, A. A. A. (2012b). Physiological, biochemical and microbiological assessment for nonconventional feedstuffs by Nile tilapia fish. Egyptian J. Nutrition and Feeds, 15 (1 Special Issue): 359-366.

Abdelhamid, A.M.; Refaey, M.M., Maklad, E.H. and Grawish, S.I. (2014). Possible effects of feeding fish the dried treated sewage sludge: I- concerning growth performance, feed utilization and chemical composition. J. Animal and Poultry prod., Mansoura Univ., 5 (10): 563-582.

Abdelhamid, A. M.;Riad, R.,Zaki, M.A.A. and Mousa, T. A. (2006b).Hemolitic activity in blood serum of Oreochromisniloticus under different types of stress. The 3rd. Int. Conf. for Develop. and the Env. In the Arab world, March, $21-$ 23, pp: $153-169$

Abou-Zied, R. M; Hassouna, M. M. E., Mohamed, R. A. and Abdl-Aziz, M. F. E. (2013). Effect of some environmental conditions and addition of palm pollen grains on the reproductive performance of red hybrid tilapia (Oreochromis sp.). Egyptian J. Nutrition and Feeds, 16 (2): 463-468.

Adhikari, L., Ghosh, L., Rai, S. P. and Ayyappan, S. (2009). Metal concentrations in water, sediment, and fish from sewage-fed aquaculture ponds of Kolkata, India Environ. Monit. Assess., 159:217-230. 
Agouz, H.M. and Gomha, A. A. (2011). Evaluation study for the impact of poultry drops, silkworm wastes and fresh rumen contents in the Nile tilapia culture. Journal of the Arabian Aquaculture Society, 6 (1): 33-48.

Deb, S.C. and Santra, S.C. (1997). Bioaccumulation of metals in fishes: an in vivo experimental study of a sewage fed ecosystem. The Environmentalist, 17: 2732.

Duncan, D. B. (1955). Multiple range and multiple F-test. Biometrics, 11: 1-42.

E.S., Egyptian standards 2360 (1993). Maximum levels for heavy metal contaminants in food. EOFS, ES: 2360 - 1993.

Escher, M.; Wahli, T., Büttner, S., Meier, W. and Burkhardt-Holm, P. (1999). The effect of sewage plant effluent on brown trout (Salmotruttafario): a cage experiment. Aquat. Sci., 61: 93-110.

Ibrahim, A. M. (2003). Ecotoxicology of some pollutants on aquatic animals.Proc. Conf. Fish Wealth and Food Safety in Arab and Islamic Countries.Azhar Univ., 22-24 Oct., $14 \mathrm{p}$.

Ibrahim, M. A., Khalafalla, M. M., Zaki, M. A. and Abd el Hamid, H. M. (2012). Physiological and nutritional studies on improving growth of Nile tilapia (Oreochromisniloticus) fingerlings using ginger root meal as a feed additive. Egyptian J. Nutrition and Feeds, 15 (1 Special Issue): 377-389.

Kakuta, I. and Murachi, S. (1997). Physiological response of carp, Cyprinuscarpio, Exposed to Raw Sewage Containing Fish Processing Wastewater. Environ. Toxicol. Water Qual., 12: 1-9.

Khalafalla, M. M., Mohsen, M. K., Eweeda, N. M., Belal, E. B. and Abozaid, S. A. (2012). Nutritional evaluation of some legumes by-products (biological treated) as a non-conventional feedstuffs in diets of Nile tilapia (Oreochromisniloticus) fingerlings. Egyptian J. Nutrition and Feeds, 15 (1 Special Issue): 337-347.

Klaasser, C.D. (2001). Casarettand Doull's Toxicology, The basic science of poisons, $6^{\text {th }}$ Ed., McGraw-Hill, North America.

Koeleman, E. (2014). Aquaculture takes over wild fisheries. All About Feed, 22 (7): $18-20$.

Ling, B., Den, T. X., Lu, Z. P., Min, L.W., Wang, Z. X. and Yuan, A. X. (1993). Use of night soil in agriculture and fish farming. World Health Forum, 14 (1): 67-70.

Medina, J., Hernadez, F., Pastor, A. and Beforull, J. B. (1986). Determination of mercury, cadmium, chromium and lead in marine organisms by flameless atomic absorption spectrophotometer. Mar. Pall. Bull., 17: $41-44$.

Park, G.S., Chung, C.S., Lee, S.H., Hong, G.H., Kim, S.H., Park, S.Y., Yoon, S.J. and Lee, S.M. (2005).Ecotoxicological evaluation of sewage sludge using bioluminescent marine bacteria and rotifer.Ocean. Sci. J., 40 (2): 91-100.

Rashed, M.N. and Awadallah, R.M. (1994). Cadmium and lead level in fish (Tilapia nilotica) scales as biological indicator for lake water pollution. Proc. Nat. Conf. on the River Nile, 10 - 14 Dec., Assiut Univ., pp. 265 - 277.

Saeed, S. M. and Mohammed, M. A. (2012). Influence of physico-chemical characteristics of water on metals accumulation in water and Tilapia zilliiin habiting different habitats in Egypt. J. of the Arab. Aqua. Soc., 7 (1): 29-50.

Saeed, S.M. and Shaker, I.M. (2008).Assessment of heavy metals pollution in water and sediments and their effect on Oreochromisniloticus in the northern delta lakes, Egypt. $8^{\text {th }}$ International Symposium on Tilapia in Aquacult., 475 pp.

Salem, M.F.I. (2003). Effect of cadmium, copper and lead contamination on growth performance and chemical composition of Nile tilapia (O. niloticus). J. Agric. Sci. Mansoura Univ., 28: 7209 - 7222. 
S A S (2001). SAS/STAT Guide for personal computer. SAS Inst. Cary, N.C.

Shata, H. A. (1996). Pollution in El-Manzala Lake, possible contribution to incidence of chronic renal failure in Dakahlia. Proc. Foodborne Contamination \& Egyptian's Health, Univ. of Mansoura, Nov. 26-27, pp: 197-200.

Welz, B. and Meleher, M. (1985).Decomposition of marine biological tissues for determination of arsenic, selenium, and mercury using hydrids-generation and cold - vopor atomic absorption spectrometries.Anal. Chem., 57: $427-431$.

Wong, M.H. and Chiu, S.T. (1993). Feasibility studies on the use of sewage sludge as supplementary feed for rearing tilapia I. Trace metal contents of the treated fish. Environmental Technology, 14 (12): 1155-1162.

Wong, M. H., Cheung, Y. H. and Lau, W. M. (1982).Toxic effects of animal manures and sewage sludge as supplementary feeds for the common carp, Cyprinuscarpio. Toxicology Letters, 12 (1): 65-73.

Yilmaz, A.B. (2005). Comparison of heavy metal levels of grey mullet (Mugilcephalus L.) and sea bream (Sparusaurota L.) caught in Iskenderun Bay (Turkey). Turk. J. Vet. Anim. Sci., 29: 257 - 262. 

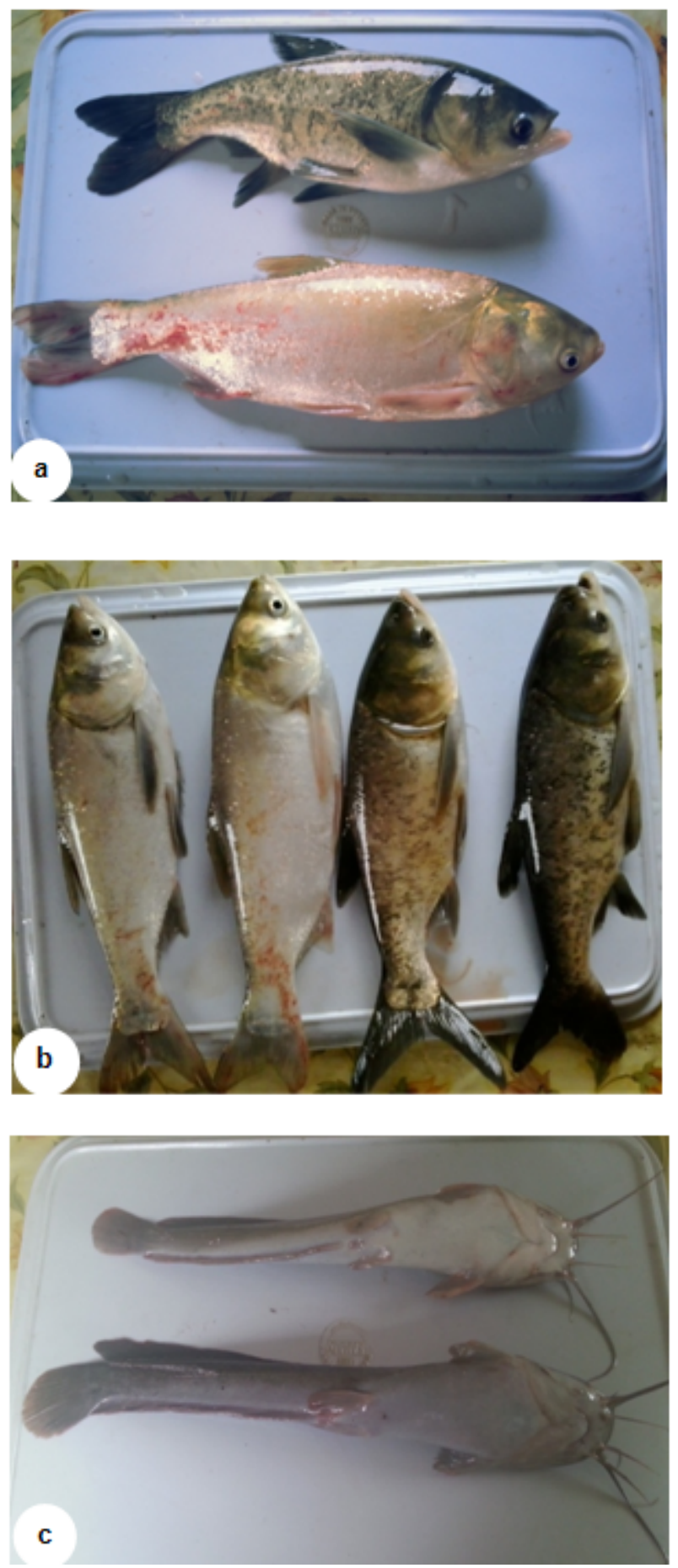

Fig. 1 (a-c): Photographs showing some morphological lesions of different fish species fed DSS or the control diet; (a): Silver carp fed DSS showing dark color of the skin and small sized (upper) compared with normal color and size of control one fed the commercial diet (lower); (b): Silver carp fed DSS showing dark color of the skin and small sized (right) compared with normal color and size of control one fed the commercial diet (left); (c): African catfish fed DSS showing dark color of the skin and large sized (lower) compared with normal color and size of the control one fed the commercial diet (upper). 


\section{ARABIC SUMMARY} التأثيرات المحتملة لتفذية الأسماك على الحمأة الجافة المعالجة على التراكم الحيوى للمعادن، العلامات

عبد الحميد محمد عبد الحميد ـ أحمد إسماعيل محرم ـ مصطفى السعيد القطان

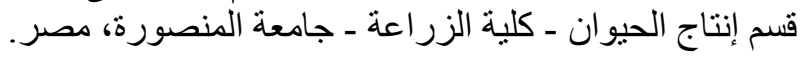

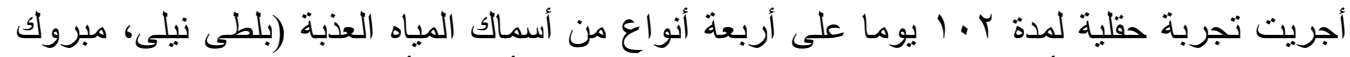

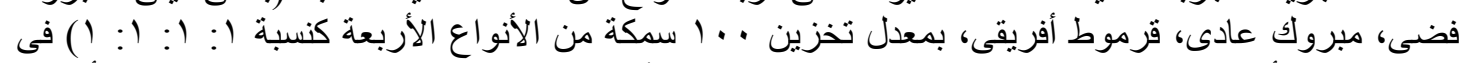

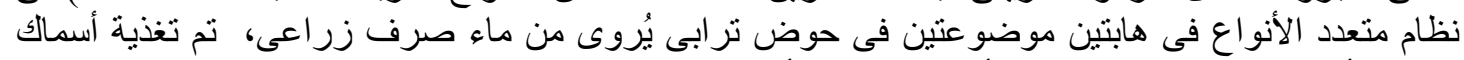

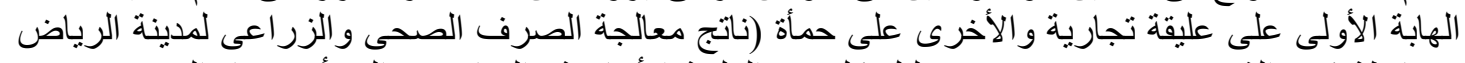

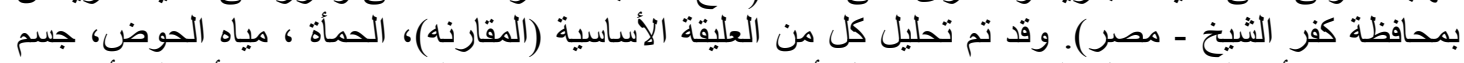

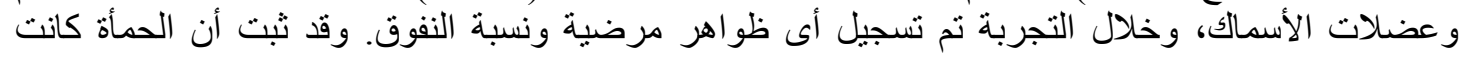

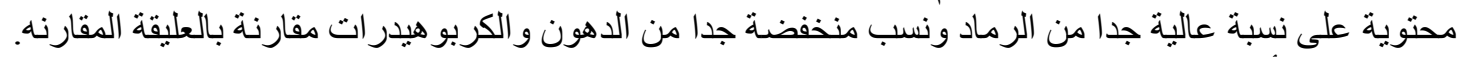

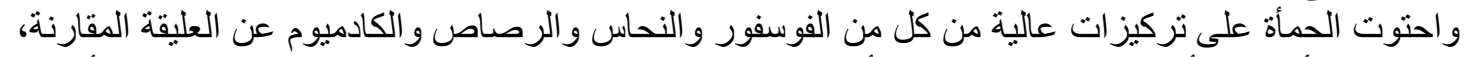

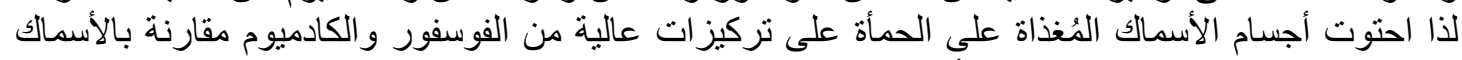

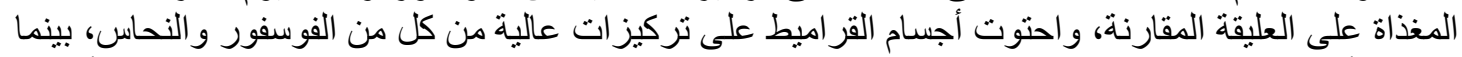

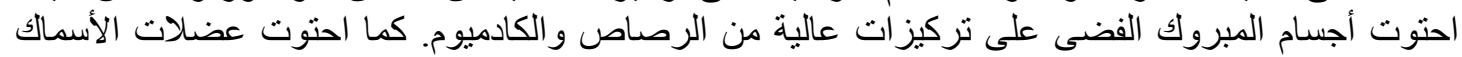

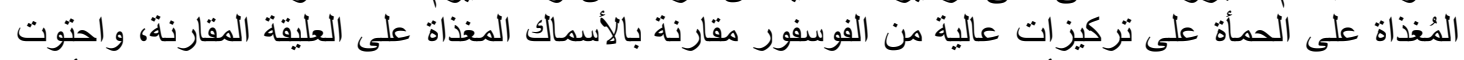

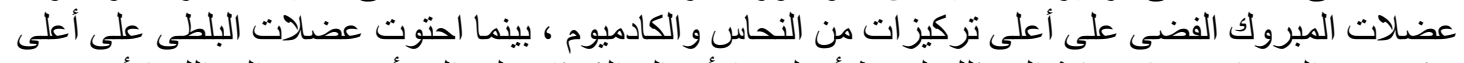

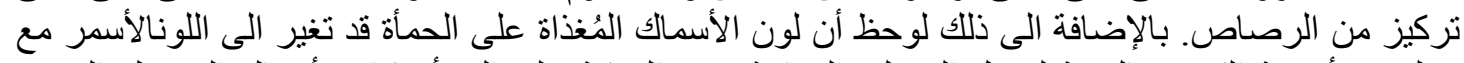

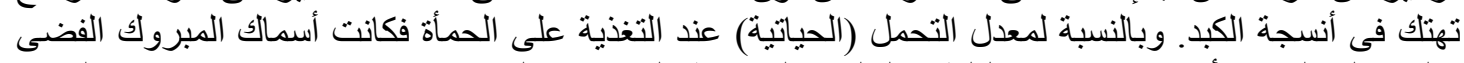

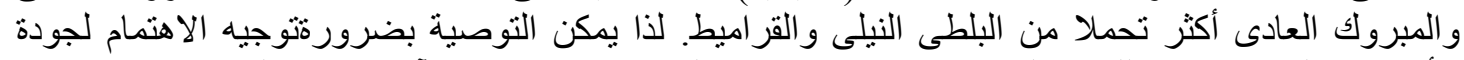

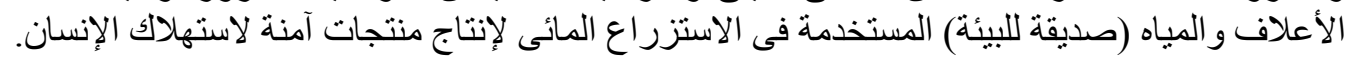

